\title{
A Probe into the Teaching Management Method of Higher Vocational Education under the Idea of "Put People First"
}

$\mathrm{NaCaO}$

Tianjin Maritime College office of teaching affairs, Tianjin, 300350

Keywords: Put People First, Teaching Management, Management Method

\begin{abstract}
Teaching work is the central work of the school, teaching management in school management plays an important role in the normal operation of teaching activities is the basis. Teaching management has the function of orientation teaching, evaluation teaching and service teaching. The level and quality of teaching management directly influence the training of qualified personnel and the quality of running a school. With the deepening of the school teaching reform, the teaching of scientific management has put forward higher requirements, how to better shape an environment, motivating people to realize the school goals and personal values of unity and strive to promote human All-round development is a new challenge to the teaching management of the school. Therefore, it is an important guarantee to improve the teaching quality of higher vocational colleges by changing the management concept and reflecting the teaching management under the people-oriented concept.
\end{abstract}

\section{Introduction}

Man is the most active, most active, the most creative elements of the management system, management activities in all the work can not do without people, people in the management of the core position of the people-oriented, is to people as the main, And the purpose of it is the recognition of the dominant position of the human, based on human practice, respect for human practice, based on the liberation of people, for the realization of human modernization and value orientation to cultivate a competitive strength of first-class talent, Our education to establish a focus on the overall development of people, emphasizing the development of human potential to the sustainable development of human needs for the first education philosophy, that is, people-oriented education philosophy of vocational education development is not only the needs of social development, Self-development needs of society and people are the mainstay of education to cultivate the society required, and comprehensive development of the people is the center of vocational education activities to implement the peopleoriented education philosophy, the implementation of people-oriented vocational education, vocational education should be fully considered The physical and mental characteristics and development needs of the current vocational education and the actual, and in the teaching management to be fully implemented.

\section{The Necessity of Establishing People - oriented Management Concept in Higher Vocational Education}

People-oriented management with advanced nature, the main idea of emphasizing people's ideological will. For teaching management, it is concerned about the student body. The purpose of putting people first is to improve students' learning enthusiasm and to provide students with a good learning environment. The so-called people who have the world, from this point, people-oriented thinking is inevitable. With the progress of teaching reform, higher vocational colleges have applied people - oriented thinking to their teaching management to help them solve complex and special problems. 
The purpose of teaching management is to promote teaching, social training and transportation personnel. People-oriented thinking is the key to improve the efficiency of management. The essence of education is to ensure the efficiency of teaching. The new management mode emphasizes the education of students. Only under the joint efforts of all can we create wealth. The reform process of the new curriculum of higher vocational education is obviously guided by the thought of people oriented. In this direction, the direction of the new curriculum reform began to change, the main performance for students to become the main teaching.

People-oriented management thinking has a certain impetus to the development of higher vocational education in our country. The traditional teaching management ignores students as the main body, while the people - oriented thinking emphasizes the idea of management hierarchy. Managers are no longer just a few people, so that students can self-management, not only improve teaching efficiency, but also reduce the pressure of higher vocational teachers. In the teaching and education process, in order to have new breakthroughs, new development, the source of power is the key. And peopleoriented management philosophy is just to meet this demand, making the management of vocational education and teaching logical.

The main performance of the lack of human management

Now Chinese higher education or the implementation of unified planning of teaching courses, students do not have the opportunity to choose their own favorite learning courses. For example, students like some of the courses can only meet some students do not even open; and some students do not like the course of the mandatory "mandatory requirements students must take elective. At the same time, in order to promote the cultural quality of education, some vocational schools Developed a rigid curriculum learning system, making the students self-selected courses greatly restricted.

In the higher vocational education system, the students are studying in the university of choice, so the selected professional can not be called on the understanding of the university will usually find themselves not suitable for the selected professional or do not like. In this case, students want to turn professional but suffer from the school system, it is difficult to get the school to allow. Although some vocational schools introduced the relevant professional system, but in line with the requirements of the few, which makes most of the students do not like their chosen professional suffer from high professional threshold can only continue to learn non-love of the professional.

Higher vocational schools have developed a certain degree of learning credit system, requiring the same professional students in the specified time to learn the same course. So that some students can not be free to learn more useful knowledge, seriously restricting the free development of students.

Quantitative management of teachers is the need for teachers to complete the quantitative work in a specified time, which increases the workload of teachers, a serious impact on teachers' teaching enthusiasm. Teachers are the main force of higher vocational schools, teachers' personality development is limited, but also affect the overall development of students.

Everyone has their own personality and style, not to mention the teacher's teaching methods, is certainly a variety of methods, while the teaching supervision is through the teaching of guidance and quality assessment of the "learning-style supervision" evaluation-style supervision, etc. Supervise teachers 'teaching methods, which affect teachers' individual teaching behavior to a certain extent, bother teachers 'class progress and restrict teachers' teaching freedom.

\section{Reasons for the Lack of Human Management}

Most of our higher vocational colleges also follow the traditional plan management model, which makes education more and more become a tool for economic growth. Students in a certain extent, did not get real attention, is still in the management of the party; and teachers are simply imparting knowledge of educational objects in the teaching management did not get the right position. Therefore, students 'self-learning and diversified learning can not be guaranteed; teachers' sense of ownership is 
weak and their status in the management system has not been implemented. On the macro-management system led to the old teaching management system is the lack of humane.

The successful establishment and continuation of higher vocational schools requires sufficient resources. There are many aspects of resources, such as: school funding, educator resources, managers, resources, material resources and so on. In the rapid development of vocational schools, growth period, the amount of resources input is far less than the increase in construction. The lack of teaching resources will limit the speed of education development, but also there will be some bad phenomena, such as: the decline in the quality of teaching; teaching base is insufficient, students can not receive education; teaching and management dereliction of duty and so on. Without adequate teaching resources, and then advanced teaching management will not be implemented.

\section{The Teaching Management Strategy of Higher Vocational Education under the People - oriented Idea}

Teaching management is the auxiliary of teaching, its goal is to promote the improvement of teaching efficiency. In teaching management, we must always adhere to the people-oriented thinking. Flexible management and people-oriented management, so that students become the main body of learning, but also allows teachers to get more management space, the use of diversified means to improve management efficiency. In the management, should establish a strict management system, pay attention to the diversification of students assessment, according to the teaching objectives of teaching management content reform. In the classroom teaching, emphasizing management, selective implementation of the classroom open, stimulate the main role of students, where conditions allow, the role of teachers and students can be exchanged, so that students can understand the feelings of teachers. Based on the needs of the people-oriented concept, higher vocational colleges can allow students to change the professional, for certain professional tendencies and outstanding students can be transferred to other professions, making management and teaching more humane. Make full use of media resources in higher vocational colleges, and promote the modernization of teaching management, so that the management of student recognition.

Management is issued, the implementation of traditional teaching management is the main feature, with the education reform, this is too formalized management methods and vocational personnel goals do not match. To cultivate diversified talents, higher vocational education should recognize the problems existing in its traditional management mechanism, understand the trend of social and economic development, adhere to the people-oriented concept, play the service role of higher educational administration. Whether teaching management or scientific research, should absorb a wide range of views, including the views of outstanding students to encourage teachers and students to understand the situation and establish a sense of service. It will serve students, service education management as its purpose. So that higher vocational management from the traditional management out of the Trinity to achieve the management. Play an individual in the management of the important role, so as to promote higher vocational teaching and management.

Teaching management services in teaching, teaching activities is the main task of higher vocational education. Therefore, the teaching management from the students, to ensure that their desire to stimulate learning, and is committed to providing a good learning environment. At present, the vocational institutions in the lack of targeted educational activities, teaching facilities outdated, and in teaching evaluation there are obvious problems. The concept of people - oriented emphasizes serving the students. In the teaching process, the teacher is the mediator of student's knowledge absorption and transformation. The task is to provide students with knowledge and learning methods, and play their guiding role to stimulate their inner potential. Work and life needs, and even training needs, which makes the concept of people-oriented teaching activities become demand. 


\section{Conclusion}

Chinese vocational colleges in the years of development, has recognized the importance of the dominant position of students. To solve this problem, adhere to the concept of people-oriented is the key, requiring teachers to update their own ideas, establish a people-oriented service and management philosophy, pay attention to the comprehensive training and evaluation of students, pay attention to teaching students to play the dominant position, so that students can feel the teaching , So that higher vocational education to meet the needs of enterprises and the community for our society to train and transport more talent to promote its sustainable development.

\section{References}

[1] Wang Yanwu, Zhu Guixi .The Application of Fine Management in the Teaching Management of Higher Vocational Colleges [J]. Chinese Science, 2016 (33)

[2] Fang Bei. "Internet +" era of higher vocational college teaching management countermeasures [J]. New campus (early) .2016 (09)

[3] Pang Yuping. Higher vocational colleges teaching management of the status quo investigation and countermeasures analysis [J]. Tomorrow fashion, 2016 (20)

[4] Fu Xiaoliang. The connotation and construction of the teaching management system in higher vocational colleges [J] .Science and Technology Vision, 2013 (33)

[5] Li Rong. The teaching management of vocational colleges [J]. Xue Weekly. 2013 (36) 